論 文

\title{
雑音抑圧のための雑音対信号比率に基づく雑音パワー推定
}

福井 勝宏 $^{1}$, 島内 未廣 ${ }^{1}$, 日岡 裕輔 $^{2}$, 中川 朗 ${ }^{1}$, 羽田 陽 ${ }^{3}$, 大室 仲 $^{1}$, 片岡 章俊 ${ }^{4}$

${ }^{1}$ 日本電信電話株式会社 NTT メディアインテリジェンス研究所, 東京都武蔵野市緑町 3-9-11

2 カンタベリー大学 電気計算機工学部, 20 Kirkwood Ave, Ilam, Christchurch 8041, ニュージーランド

3 電気通信大学大学院 情報理工学研究科 総合情報学専攻，東京都調布市調布ヶ丘 1-5-1

4 龍谷大学 理工学部 情報メディア学科, 滋賀県大津市瀬田大江町横谷 1-5

\section{Noise-Power Estimation Based on Ratio of Stationary Noise to Input Signal for Noise Reduction}

Masahiro Fukui ${ }^{1}$, Suehiro Shimauchi ${ }^{1}$, Akira Nakagawa ${ }^{1}$, Yusuke Hioka ${ }^{2}$, Yoichi Haneda ${ }^{3}$, Hitoshi Ohmuro ${ }^{1}$ and Akitoshi Kataoka ${ }^{4}$

${ }^{1}$ NTT Media Intelligence Laboratories, NTT Corporation, 3-9-11 Midori-cho, Musashino-shi, Tokyo 180-8585, Japan

${ }^{2}$ Department of Electrical and Computer Engineering, University of Canterbury, 20 Kirkwood Ave, Ilam, Christchurch 8041, New Zealand

${ }^{3}$ Faculty of Informatics and Engineering, The University of Electro-Communications, 1-5-1 Chofugaoka, Chofu-shi, Tokyo 182-8585, Japan

${ }^{4}$ Faculty of Science and Technology, Ryukoku University, 1-5 Yokotani, Seta Oe-cho, Otsu-shi, Shiga 520-2914, Japan

E-mail: fukui.masahiro@lab.ntt.co.jp

\begin{abstract}
This paper proposes a method for estimating noise-power spectrum and reducing stationary noise components in noisy speech signal. Noise reduction generally suppresses the stationary noise by applying a multiplicative gain calculated from the estimated noise-power spectrum. However, the accuracy of the noise-power estimation is degraded by the presence of superimposed speech. The proposed method aims to maintain the accuracy of the noise-power estimation in a period of speech. The method first estimates the power ratio of noise to input signal for each frequency bin by assuming the noise amplitude spectrum to be constant in a short time period which cannot be applied to the amplitude spectrum of speech. The method then improves the estimation accuracy by compensating for the errors caused by time variations in the stationary noise. Simulation results demonstrate the accuracy improvement of the noise-power estimation for the stationary noise and the better performance in terms of noise reduction.
\end{abstract}

Keywords: noise-power estimation, noise reduction, short-time spectral amplitude estimation, Wiener filter 


\section{1. はじめに}

TV 会議に代表される遠隔地を結ぶ通信会議におい て，オフィスの空調音など，周囲雑音の存在する騒が しい環境でも十分なハンズフリー通話品質を達成する ことが望まれている。こうした背景を踏まえ，近年， 音声通話の品質劣化の原因となる周囲雑音を抑圧す る機能を備えたハンズフリー通信機器の研究開発が行 われている [1], [2]。代表的な周囲雑音の抑圧処理と しては，スペクトルサブトラクション法 [3] などの短 時間スペクトル振幅 (short-time spectral amplitude: STSA）推定に基づいた雑音抑圧処理 [3]-[6] がある。 STSA 雑音抑圧処理は, 1 チャンネル入力系の周波数 領域処理であり, 周囲雑音が混入した音声入力信号の 短時間スペクトル振幅成分に雑音抑圧ゲインを重畳し て, 周囲雑音を抑圧し音声を強調する。この処理は, 周波数ごとの雑音パワーの推定值に基づいて入力信号 に含まれる雑音成分を抑圧するため, 雑音パワーの推 定精度が抑圧処理後の音声品質に大きく関わる。この ことは，入力信号に音声が含まれる区間（音声区間） において, 周囲雑音が変動する場合に特に重要となる。

雑音パワー推定において, 音声区間検出（voice activity detection：VAD）[7] を用い, 音声が存在しな いと判断された区間から雑音パワーを取得する手法 [3]-[5] が提案されている。しかしながら，こうした手 法では, 音声区間中の周囲雑音の変動に追従できない 問題がある。そのため, VAD を用いない, 音声区間で も継続的に雑音パワーを推定する手法として，パワー スペクトル平均值の最小值を周波数ごとに求め, 現時 刻の雑音パワーとする手法 [8]-[13] が広く利用されて いる。しかしながら，この手法は，音声区間が長時間 継続すると, 音声成分の影響により, 雑音パワーを過 大推定してしまい, 結果として推定精度が低下してし まう場合がある。

そこで本論文では, STSA雑音抑圧処理における重 要なパラメータである雑音パワーについて, 入力信号 パワーに含まれる雑音パワーの割合（雑音対信号比率 〔noise-to-signal ratio〕) を得ることで音声区間におい ても継続的に推定する手法を提案する。提案手法では, 定常雑音の周波数ごとの振幅が短区間では一定值とみ なすことができ，且つ音声成分が非定常であることを 仮定することで, 現時刻の雑音対信号比率を一次推定 する。更に, 雑音対信号比率の推定精度の向上を図る ため, 雑音対信号比率の一次推定值がもつ, 周囲雑音 の周波数振幅が一定であるという仮定と, 実際には振 幅が時変であることとのずれを補正することを行う。
以下，2. で STSA 雑音抑圧処理について説明し， 3. で従来の雑音パワー推定手法とその問題点について述 べる。提案する雑音パワー推定手法を 4. で説明し, 計 算機シミュレーションによる評価実験結果を 5 . で示 す。6. でまとめと今後の課題を述べる。

\section{STSA 雑音抑圧処理}

図 1 にSTSA 雑音抑圧処理の構成例 [2] を示す。音声 を $s(k)$, 周囲雑音を $n(k)$ とすると, 入力信号は $x(k)=$ $s(k)+n(k)$ となる。入力信号, 音声および周囲雑音 の短時間スペクトルをそれぞれ $X_{i}(\omega), S_{i}(\omega), N_{i}(\omega)$ とすると,

$$
X_{i}(\omega)=S_{i}(\omega)+N_{i}(\omega)
$$

と表される。ここで，iは短時間フーリエ変換の処理 フレーム番号， $\omega$ は離散的な周波数を表す整数である。 STSA 雑音抑圧処理は, 入力信号スペクトル $X_{i}(\omega)$ に 実数の雑音抑圧ゲイン $G_{i}(\omega)$ を乗ずることで，周囲雑 音を抑圧して音声を強調する。すなわち，音声スペク トルの推定值 $\hat{S}_{i}(\omega)$ は,

$$
\hat{S}_{i}(\omega)=G_{i}(\omega) X_{i}(\omega)
$$

と推定される。例えば, ウィーナーフィル夕法 [4] と 原音付加方式 [14] を組み合わせた場合，雑音抑圧ゲイ ン $G_{i}(\omega)$ は,

$$
G_{i}(\omega)=\alpha+(1-\alpha) \frac{\left|X_{i}(\omega)\right|^{2}-E\left[\left|\hat{N}_{i}(\omega)\right|^{2}\right]}{\left|X_{i}(\omega)\right|^{2}}
$$

と与えられる $[2] 。 こ こ て ゙ ， \alpha は ， 1$ 以下の正の定数で あり，未処理の原信号の付加割合を意味する。 $E[\cdot]$ は 集合平均を表し,

$$
E\left[P_{i}(\omega)\right]=\frac{1}{L} \sum_{l=0}^{L-1} P_{i-l}(\omega)
$$

として計算される。ここで, $L$ はフレーム数, $P_{i}(\omega)$ は スペクトルを表す。式 $(3)$ に示す $E\left[\left|\hat{N}_{i}(\omega)\right|^{2}\right]$ は，周波 数ごとの雑音パワー平均值（以下,「雑音パワー」とい う。）である $E\left[\left|N_{i}(\omega)\right|^{2}\right]$ の推定值を表す。式 (3) から わかるように, 雑音抑圧ゲイン $G_{i}(\omega)$ を求めるには, 雑音パワー $E\left[\left|N_{i}(\omega)\right|^{2}\right]$ を推定する必要がある。した がって, 雑音抑圧性能は, 雑音パワー推定精度に大き く左右される。

\section{3. 従来の雑音パワー推定手法とその問題}

2. で述べたように，STSA 雑音抑圧処理において， 雑音抑圧ゲイン $G_{i}(\omega)$ を高精度に求めるには, 雑音パ

Journal of Signal Processing, Vol. 18, No. 1, January 2014 


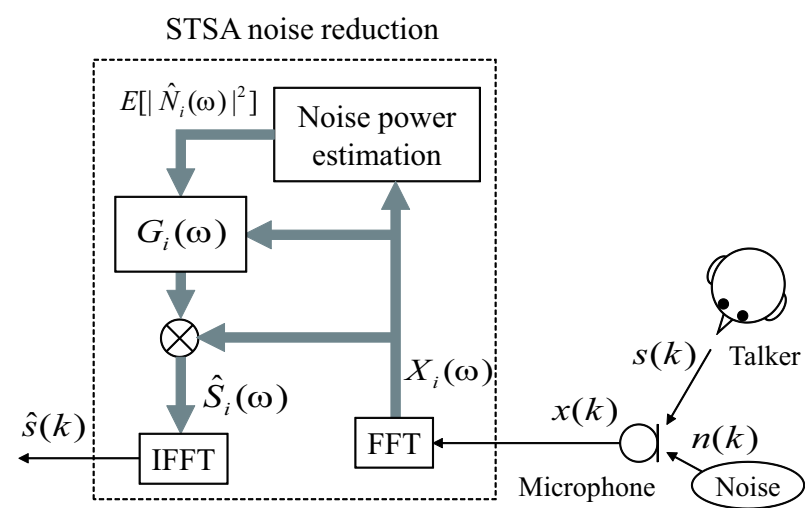

図 1 STSA 雑音抑圧処理のブロック図

Fig. 1 Block diagram of STSA noise reduction

ワー $E\left[\left|N_{i}(\omega)\right|^{2}\right]$ の推定精度が重要となる。ここでは, $\mathrm{VAD}$ を用いず，音声区間においても継続的に雑音パ ワーを推定する手法として文献 [8] を取り上げ，その 問題点について議論する。

\section{1 従来手法}

従来の雑音パワー推定手法 [8] は, 入力信号のパワー が小さい区間では音声がほとんどないと仮定し, 周波 数ごとの入力信号のパワースペクトル平均值における, 閉区間 $[i-L+1, i]$ 内の最小值を雑音パワーとする手 法である。雑音パワーの推定值 $E\left[\left|\hat{N}_{i}(\omega)\right|^{2}\right]$ は,

$$
E\left[\left|\hat{N}_{i}(\omega)\right|^{2}\right]=\kappa \min _{l=0, \cdots, L-1}\left\{\Psi\left[\left|X_{i-l}(\omega)\right|^{2}\right]\right\}
$$

として計算される。ここで， $\kappa$ は, 最小值と平均値の 間の誤差を補償する定数である。 $\min \{\cdot\}$ は最小値選 択を意味する。 $\Psi[\cdot]$ は, 移動平均を求める処理を表し,

$$
\Psi\left[P_{i}(\omega)\right]=\epsilon \Psi\left[P_{i-1}(\omega)\right]+(1-\epsilon) P_{i}(\omega)
$$

として計算される。ここで， $\epsilon$ は， $0<\epsilon<1$ を満た す忘却係数であり，指数関数的な減衰の割合を決定す る。式 (5) に示すように, 時系列の分散が大きい瞬時值 $\left|X_{i}(\omega)\right|^{2}$ ではなく, 分散の小さな平均值 $\Psi\left[\left|X_{i}(\omega-l)\right|^{2}\right]$ を用いることで, 雑音パワー推定值となる最小值が, 目標とする雑音パワーから大きく外れることを防止し ている。

\section{2 従来手法の問題点}

従来の雑音パワー推定手法の問題点は, 雑音パワー $E\left[\left|N_{i}(\omega)\right|^{2}\right]$ を推定するために, 入力信号のパワースペ クトル平均值 $\Psi\left[\left|X_{i}(\omega)\right|^{2}\right]$ の閉区間 $[i-L+1, i]$ 内に, 音声成分がほとんどない区間を必要とする点である。

3.1 で述べたように, 従来手法において, 推定精度 を保つためには，パワー時系列の分散が小さいほどよ い。しかしながら, 分散を小さくするために, $\epsilon$ の值を 大きく設定することで $\Psi\left[\left|X_{i}(\omega)\right|^{2}\right]$ を求める移動平均 の区間を長くすれば，周囲雑音だけでなく音声も平均 され，音声成分が含まれない区間が閉区間 $[i-L+1, i]$ 内に現れず，雑音パワーを過大推定してしまう可能性 がある。一方，これを補うために閉区間を十分に長く 設定すると, 雑音変動に対する追従性が低下してしま $う^{1}$ 。従来手法では, VAD を必要としないものの, 音 声区間中における雑音パワー推定の精度低下が懸念さ れる。

\section{4. 提案する雑音パワー推定手法}

3.2 で述べたように，従来手法 [8] では，音声区間 中の雑音パワー推定において, 精度低下を伴う問題が ある。そこで筆者らは, 雑音パワー推定精度の改善を 目的とし, 雑音対信号比率に基づく雑音パワー推定手 法を提案する。本手法は, 従来手法と同様に, 雑音パ ワー推定のために VAD を必要とせず, 音声区間と, 音 声のない周囲雑音のみの区間（雑音区間）を区別する ことなく処理が行われる。提案手法は, 雑音パワー推 定の基本処理と雑音対信号比率推定値の補正処理の 2 つのステップからなる。

\section{1 雑音パワー推定の基本処理}

提案する雑音パワー推定手法では, 雑音対信号比率 $\gamma_{i}(\omega)$ から, 雑音パワー $E\left[\left|N_{i}(\omega)\right|^{2}\right]$ を

$$
E\left[\left|N_{i}(\omega)\right|^{2}\right]=\gamma_{i}(\omega) E\left[\left|X_{i}(\omega)\right|^{2}\right]
$$

として求めることを考える。ここで, 式 (7) の雑音対 信号比率 $\gamma_{i}(\omega)$ は，式 (4) より次のようになる。

$$
\gamma_{i}(\omega)=\frac{E\left[\left|N_{i}(\omega)\right|^{2}\right]}{E\left[\left|X_{i}(\omega)\right|^{2}\right]}
$$

\footnotetext{
1 雑音パワー推定值は, 区間内の最小值が更新されるまで不変で あるため。
} 


$$
\begin{aligned}
= & \frac{\frac{1}{L} \sum_{l=0}^{L-1}\left|N_{i-l}(\omega)\right|^{2}}{\frac{1}{L} \sum_{l=0}^{L-1}\left|X_{i-l}(\omega)\right|^{2}} \\
= & \frac{\sum_{l=0}^{L-1}\left|N_{i-l}(\omega)\right|^{2}}{\sum_{l=0}^{L-1}\left|X_{i-l}(\omega)\right|^{2}}
\end{aligned}
$$

式(10)において, $\sum_{l=0}^{L-1}\left|N_{i-l}(\omega)\right|^{2}$ が未知であるた め, 雑音対信号比率 $\gamma_{i}(\omega)$ を計算することはできない。 そこで本手法では,

(i ) 閉区間 $[i-L+1, i]$ 内で, 周囲雑音の周波数振 幅 $\left|N_{i}(\omega)\right|$ が時間によらず常に一定（定数）

(ii ) 音声の周波数振幅 $\left|S_{i}(\omega)\right|$ が非定常

であれば，コーシー=シュワルツの不等式により，

$$
\begin{aligned}
& \left(\frac{1}{L} \sum_{l=0}^{L-1}\left|N_{i-l}(\omega)\right|\right)^{2} \approx \frac{1}{L} \sum_{l=0}^{L-1}\left|N_{i-l}(\omega)\right|^{2} \\
& \left(\frac{1}{L} \sum_{l=0}^{L-1}\left|S_{i-l}(\omega)\right|\right)^{2} \ll \frac{1}{L} \sum_{l=0}^{L-1}\left|S_{i-l}(\omega)\right|^{2}
\end{aligned}
$$

と仮定し, 雑音対信号比率の推定値 $\hat{\gamma}_{i}(\omega)$ を求める。 式 (12) では, $\left|S_{i-l}(\omega)\right|$ が非定常性の高い係数である とき, 左辺が右辺より十分に小さいものと考える。本 仮定の妥当性確認と検証については後述する。式 (12) 左辺の $\left(\frac{1}{L} \sum_{l=0}^{L-1}\left|S_{i-l}(\omega)\right|\right)^{2}$ を誤差成分 $\delta_{S}$ とし, 式 (1), 式 (11), および式 (12)より, 雑音パワーの推定 值 $E\left[\left|\hat{N}_{i}(\omega)\right|^{2}\right]$ を入力信号スペクトル $X_{i}(\omega)$ から次式 のように近似的に求める。

$$
\begin{aligned}
E\left[\left|\hat{N}_{i}(\omega)\right|^{2}\right] & \approx\left(\frac{1}{L} \sum_{l=0}^{L-1}\left|X_{i-l}(\omega)\right|\right)^{2} \\
& =\left(\frac{1}{L} \sum_{l=0}^{L-1}\left|S_{i-l}(\omega)+N_{i-l}(\omega)\right|\right)^{2} \\
& \approx \delta_{S}+\left(\frac{1}{L} \sum_{l=0}^{L-1}\left|N_{i-l}(\omega)\right|\right)^{2} \\
& \approx \frac{1}{L} \sum_{l=0}^{L-1}\left|N_{i-l}(\omega)\right|^{2}
\end{aligned}
$$

上記の近似展開では, $\left|S_{i-l}(\omega)\right|$ が非定常性の高い係数 で值が小さいとして $\delta_{S}$ を無視し, 雑音レベルを導出
した。式 (8), 式 (9), および式 (13)より, 雑音対信 号比率の推定値 $\hat{\gamma}_{i}(\omega)$ は次式で与えられる。

$$
\begin{aligned}
& \hat{\gamma}_{i}(\omega)=\frac{E\left[\left|\hat{N}_{i}(\omega)\right|^{2}\right]}{E\left[\left|X_{i}(\omega)\right|^{2}\right]} \\
&=\frac{\left(\frac{1}{L} \sum_{l=0}^{L-1}\left|X_{i-l}(\omega)\right|\right)^{2}}{\frac{1}{L} \sum_{l=0}^{L-1}\left|X_{i-l}(\omega)\right|^{2}} \\
&=\frac{\left(\sum_{l=0}^{L-1}\left|X_{i-l}(\omega)\right|\right)^{2}}{L-1}\left|X_{i-l}(\omega)\right|^{2} \\
& L=0
\end{aligned}
$$

式 (19) からわかるように, 提案する雑音対信号比 率推定值 $\hat{\gamma}_{i}(\omega)$ は, 入力信号の周波数ごとの振幅時系 列に含まれる定常成分の割合（以下，「定常成分対信号 比率」と称す) に等しい。入力信号スペクトル $X_{i}(\omega)$ を $P_{i}(\omega)$ に置き換え一般化し, 定常成分対信号比率 $\hat{\gamma}_{i}(\omega)^{\mathrm{P}}$ を次式として与える。

$$
\hat{\gamma}_{i}(\omega)^{\mathrm{P}}=\frac{\left(\sum_{l=0}^{L-1}\left|P_{i-l}(\omega)\right|\right)^{2}}{L \sum_{l=0}^{L-1}\left|P_{i-l}(\omega)\right|^{2}}
$$

これら $\hat{\gamma}_{i}(\omega)$ および $\hat{\gamma}_{i}(\omega)^{\mathrm{P}}$ は，ある離散周波数 $\omega て ゙$, 雑音のような定常成分が占める割合が大きいとき，そ の周波数で $\hat{\gamma}_{i}(\omega)$ が 1 に近い值となる。反対に, 音声 のような非定常成分が占める割合が大きいとき， 0 に 近い值となる。

ここで, 本手法の仮定（i ）および（ii）の妥当 性について述べる。図 2 に, 式 (20) より求めた周囲 雑音, 音声, および雑音重畳音声の定常成分対信号比 率 $\hat{\gamma}_{i}(\omega)^{\mathrm{N}}, \hat{\gamma}_{i}(\omega)^{\mathrm{S}}, \hat{\gamma}_{i}(\omega)^{\mathrm{S}+\mathrm{N}}$ をそれぞれ示す。縦軸 が定常成分対信号比率, 横軸が周波数を表す。実線は 空調雑音を用いた場合の定常成分対信号比率 $\hat{\gamma}_{i}(\omega)^{\mathrm{N}}$, 太点線は音声として男声を与えた場合の定常成分対信 号比率 $\hat{\gamma}_{i}(\omega)^{\mathrm{S}}$, 破線は空調雑音に音声を加えた雑音重 畳音声の定常成分対信号比率 $\hat{\gamma}_{i}(\omega)^{\mathrm{S}+\mathrm{N}}$ を示す。定常 成分対信号比率 $\hat{\gamma}_{i}(\omega)^{\mathrm{N}}, \hat{\gamma}_{i}(\omega)^{\mathrm{S}}$, および $\hat{\gamma}_{i}(\omega)^{\mathrm{S}+\mathrm{N}}$ は それぞれ，

$$
\hat{\gamma}_{i}(\omega)^{\mathrm{N}}=\frac{\left(\sum_{l=0}^{L-1}\left|N_{i-l}(\omega)\right|\right)^{2}}{L \sum_{l=0}^{L-1}\left|N_{i-l}(\omega)\right|^{2}}
$$




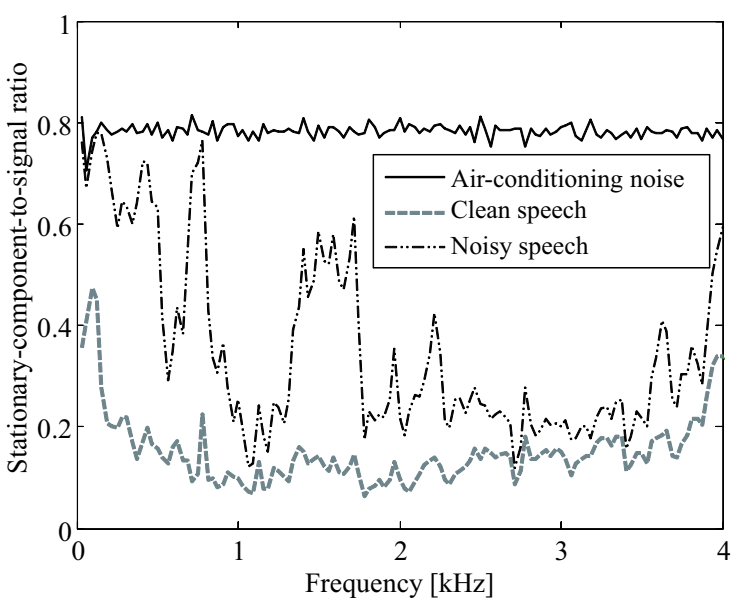

図 2 空調雑音, 音声, および雑音重畳音声の定常 成分対信号比率

Fig. 2 Stationary-component-to-signal ratio for airconditioning noise, clean speech, and noisy speech

$$
\begin{gathered}
\hat{\gamma}_{i}(\omega)^{\mathrm{S}}=\frac{\left(\sum_{l=0}^{L-1}\left|S_{i-l}(\omega)\right|\right)^{2}}{L \sum_{l=0}^{L-1}\left|S_{i-l}(\omega)\right|^{2}} \\
\hat{\gamma}_{i}(\omega)^{\mathrm{S}+\mathrm{N}}=\frac{\left(\sum_{l=0}^{L-1}\left|S_{i-l}(\omega)+N_{i-l}(\omega)\right|\right)^{2}}{L-1}\left|\sum_{l=0}^{L-1}\right| S_{i-l}(\omega)+\left.N_{i-l}(\omega)\right|^{2}
\end{gathered}
$$

として求めた。式 (1)の関係より, 式 (23) の雑音重畳 音声の定常成分対信号比率 $\hat{\gamma}_{i}(\omega)^{\mathrm{S}+\mathrm{N}}$ は, 式 (19) の雑 音対信号比率 $\hat{\gamma}_{i}(\omega)$ に等しい。図 2 からわかるように， 周囲雑音の場合は全ての周波数帯域においてこの比率 が 0.8 前後であるのに対し，音声の場合は平均で 0.15 程度である。雑音重曽信号における比率は, 周囲雑音 における比率と音声における比率の間の值（平均で約 0.35）をとる。また，周囲雑音に関して，車内雑音お よび街頭雑音を用いたの定常成分対信号比率を図 3 に 示す。本図より，これらの周囲雑音でも比率が 0.7 0.8 程度と高いことが分かる。これらのことから, 仮 定（i ）および（ ii ）の妥当性が高いと判断できる。

\section{2 雑音対信号比率推定值の補正処理}

4.1 で述べたように，雑音対信号比率の推定值 $\hat{\gamma}_{i}(\omega)$ は, 入力信号の定常成分対信号比率による近似值であ

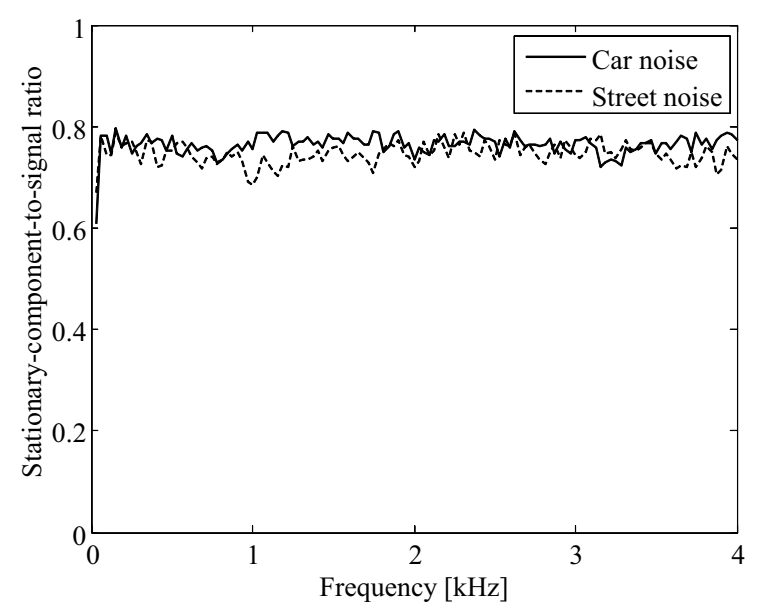

図 3 車内雑音と街頭雑音の定常成分対信号比率

Fig. 3 Stationary-component-to-signal ratio for car and street noises

る。しかしながら，実際には，周囲雑音の周波数振幅 は一定值でなく分散を含むものであるため, 図 2 お よび図 3 に示すように, 周囲雑音の定常成分対信号 比率が 1 とはならない。また, 音声の周波数振幅が $\left|S_{i}(\omega)\right| \geq 0$ であるため, 同図に示すように, 音声の 定常成分対信号比率は 0 に近い值をとるが 0 とはなら ない。これらのことから, 上述した雑音対信号比率推 定值 $\hat{\gamma}_{i}(\omega)$ に誤差が生じてしまう。そこで, この誤差 を補正するために, 推定值 $\hat{\gamma}_{i}(\omega)$ を 1 または 0 に近づ けるように，図 2 に示す雑音と音声のそれぞれの定常 成分対信号比率 $\hat{\gamma}_{i}(\omega)^{\mathrm{N}}, \hat{\gamma}_{i}(\omega)^{\mathrm{S}}$ に基づいた強調化を 行う。強調化した後の雑音対信号比率推定值を $\hat{\gamma}_{i}(\omega)^{\mathrm{C}}$ として，強調化の 1 つの方法を次式に示す。

$\hat{\gamma}_{i}(\omega)^{\mathrm{C}}= \begin{cases}a_{1}(\omega) \hat{\gamma}_{i}(\omega)+b_{1}(\omega), & \text { if } \hat{\gamma}_{i}(\omega)>c_{\text {mid }}(\omega) \\ a_{2}(\omega) \hat{\gamma}_{i}(\omega)+b_{2}(\omega), & \text { otherwise }\end{cases}$

ここで, $a_{1}(\omega)$ と $a_{2}(\omega)$ は傾き, $b_{1}(\omega)$ と $b_{2}(\omega)$ は切 片， $c_{\text {mid }}(\omega)$ は閾值を表し，それぞれ，

$$
\begin{aligned}
a_{1}(\omega) & =\frac{0.5}{c_{\max }(\omega)-c_{\operatorname{mid}}(\omega)} \\
a_{2}(\omega) & =\frac{0.5}{c_{\operatorname{mid}}(\omega)-c_{\min }(\omega)} \\
b_{1}(\omega) & =0.5\left\{1-\frac{c_{\operatorname{mid}}(\omega)}{c_{\max }(\omega)-c_{\operatorname{mid}}(\omega)}\right\} \\
b_{2}(\omega) & =-0.5 \frac{c_{\min }(\omega)}{c_{\operatorname{mid}}(\omega)-c_{\min }(\omega)} \\
c_{\text {mid }}(\omega) & =\frac{c_{\max }(\omega)+c_{\min }(\omega)}{2}
\end{aligned}
$$




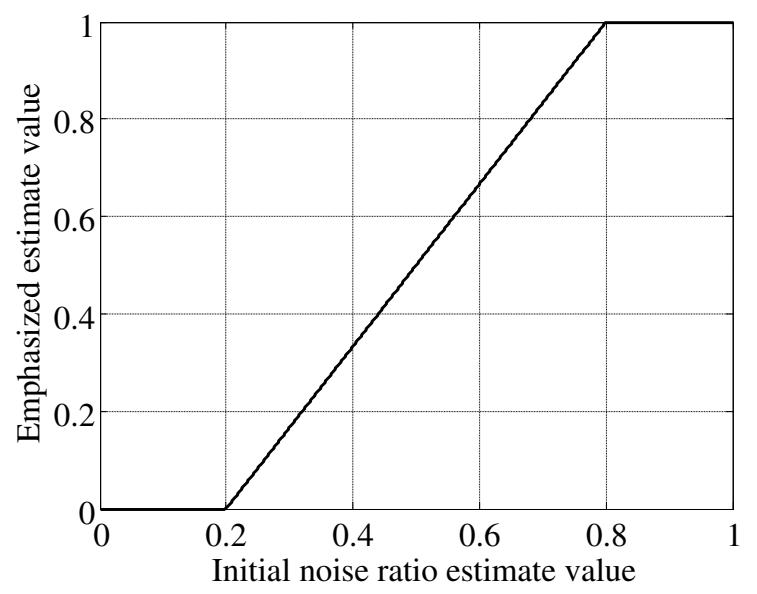

図 4 強調化の入出力特性例

Fig. 4 Input-output characteristic example on emphasis processing

として与える。ただし, $c_{\max }(\omega)$ は, 雑音の定常成分 対信号比率 $\hat{\gamma}_{i}(\omega)^{\mathrm{N}}$ に相当する定数, $c_{\min }(\omega)$ は, 音声 の定常成分対信号比率 $\hat{\gamma}_{i}(\omega)^{\mathrm{S}}$ に相当する定数である。 式 $(24)$ は, 傾き $a_{1}(\omega)$ および $a_{2}(\omega)$, 切片 $b_{1}(\omega)$ およ び $b_{2}(\omega)$ の直線の回帰式であり, 定数 $c_{\max }(\omega)$ および $c_{\min }(\omega)$ の設定によって, 推定值 $\hat{\gamma}_{i}(\omega)$ の強調の割合を 制御することができる。図 4 に, 定数 $c_{\max }(\omega)=0.8$, $c_{\min }(\omega)=0.2$ に設定したときの, 式 $(24)$ から得られ る強調化の入出力特性を示す。横軸が元の雑音対信号 比率推定值 $\hat{\gamma}_{i}(\omega)$, 縦軸が強調化した後の雑音対信号 比率推定值 $\hat{\gamma}_{i}(\omega) \mathrm{C}$ を表す。

雑音対信号比率 $\gamma_{i}(\omega)$ とその推定值 $\hat{\gamma}_{i}(\omega)$, 図 4 に 示す強調化後の推定值 $\hat{\gamma}_{i}(\omega)^{\mathrm{C}}$ の時間推移の例を図 5 に示す。縦軸が比率, 横軸が時間を表す。薄線は雑音 対信号比率 $\gamma_{i}(\omega)$, 点線はその推定值 $\hat{\gamma}_{i}(\omega)$, 実線は強 調化後の推定值 $\hat{\gamma}_{i}(\omega)^{\mathrm{C}}$ を示す。図 5 からわかるよう に, 閾值 $c_{\text {mid }}(\omega)=0.5$ を境界線として, 雑音対信号 比率推定值 $\hat{\gamma}_{i}(\omega)$ を 1 または 0 に近づけるように強調 化がなされている。このように，不完全さをもつ仮定 （ i ），（ ii ）のために生じる䛊差を強調化で補正する ことによって, 推定值を目標值 $\gamma_{i}(\omega)$ に近づけること ができる。提案手法では, 上述した強調化後の雑音対 信号比率推定值 $\hat{\gamma}_{i}(\omega) \mathrm{C}$ を用いて, 雑音パワー推定值 $E\left[\left|\hat{N}_{i}(\omega)\right|^{2}\right]$ を次式のように計算する。

$$
E\left[\left|\hat{N}_{i}(\omega)\right|^{2}\right]=\frac{\hat{\gamma}_{i}(\omega)^{\mathrm{C}}}{L} \sum_{l=0}^{L-1}\left|X_{i-l}(\omega)\right|^{2}
$$

本章のまとめとして 4.1 と 4.2 で述べた雑音パワー

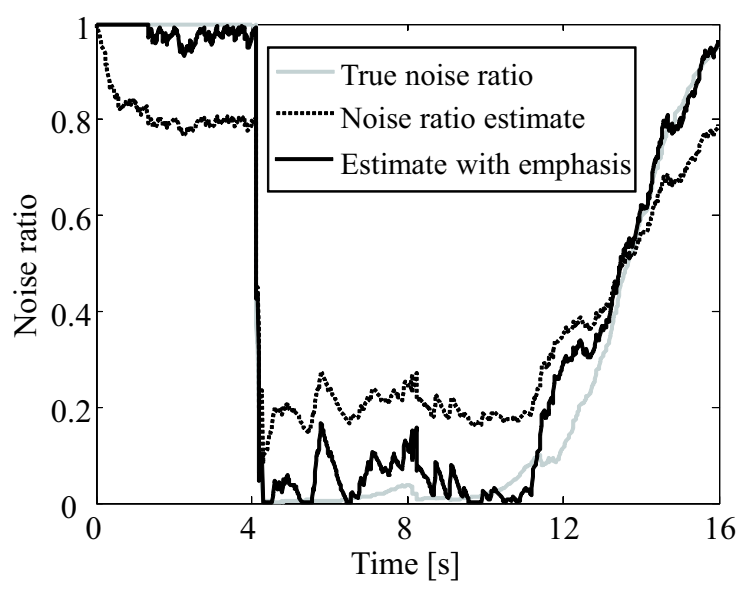

図 $51 \mathrm{kHz}$ での雑音対信号比率の真值および推定 值の時間推移

Fig. 5 Time changes of true noise-to-signal ratio and its estimate at $1 \mathrm{kHz}$

推定および推定值の補正処理について, それぞれの処 理の流れを図 6 に示す。

\section{5. 評価実験}

提案手法の有効性を確認するため, 雑音パワー推定 精度と杂隹音抑圧性能について, 従来手法 [8] と提案手法 の比較評価をシミュレーション実験により行つた。雑 音抑圧の性能については，2. で述べたウィーナーフィ ル夕法に基づく STSA 雑音抑圧処理 [2] を用いて検証 した。

\section{1 実験条件}

雑音パワー推定値の算出として, 従来手法は式 (5), 提案手法は式 (30)をそれぞれ用いた。標本化周波数を $8 \mathrm{kHz}$, 周波数処理を行う際の処理フレーム長を 256 点 $(32 \mathrm{~ms})$ とし, 1/2 オーバーラップ加算による分 析合成を用いて計算機シミュレーションを行った。パ ラメータ $L, \epsilon, \kappa$ について $L=50(1 / 2$ オーバー ラップにより $16 \mathrm{~ms}$ ずつフレームシフトするため, 50 フレームは $0.8 \mathrm{~s}$ に相当)， $\epsilon=0.9, \kappa=1.5$ と文献 [8] に示されている值を用いた。音声 $s(k)$ として, 図 7 に示す女声を与えた ${ }^{2}$ 。図中の音声サンプルは，8秒

2 結果の妥当性を図るため, 図 2 および図 3 で用いた音声とは 別の信号を用いて試験を行った。

Journal of Signal Processing, Vol. 18, No. 1, January 2014 


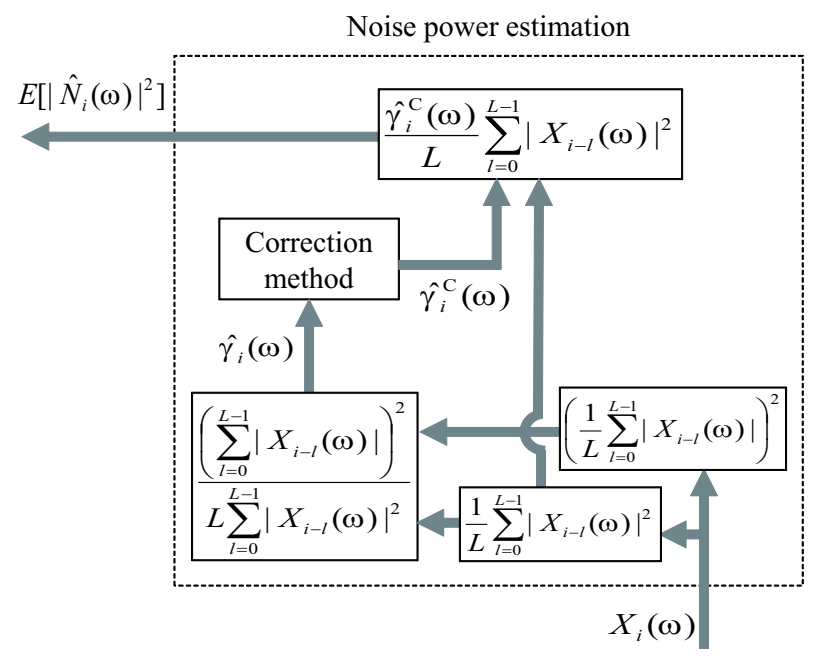

図 6 提案手法のブロック図

Fig. 6 Block diagram of proposed method

程度の短文章を発声し ${ }^{3}$, 国際電気通信連合 電気通信 標準化部門 (International Telecommunication Union Telecommunication Standardization Sector : ITU-T) 勧告 P. $800[15]$ に準拠して録音され，その後，8秒の 無音信号を加え，作成された。

周囲雑音 $n(k)$ として, 定常である空調雑音と, 時 間変動を伴う車内雑音および街頭雑音，および夕イピ ング音や会話など非定常音を伴うオフィス雑音の 4 種 類を用いた。これらの雑音サンプルは，それぞれ，電 子協騒音データベース [16]の「空調機」, NTT アドバ ンステクノロジ株式会社の環境騒音データベース [17] の「コンパクトカー」「市街道路」「「オフィス内」のサ ンプルである。空調雑音, 車内雑音, および街頭雑音 は, 図 2 および図 3 に示すように定常成分対信号比率 が高く, 仮定（i）が成り立つ場合の性能評価として 用いられる。これに対し，オフィス雑音は，話し声や 物音などを含み非定常性が高く，仮定（i）が成り立 たない場合の性能評価として用いられる。入力信号の SNR（Signal-to-noise ratio）は，それぞれ $0 \mathrm{~dB} ，-6$ $\mathrm{dB}, 6 \mathrm{~dB}, 9 \mathrm{~dB}$ とした。

\footnotetext{
3 発話の内容を，夏目漱石著「坊っちゃん」より引用し，「小学校 に居る時分学校の二階から飛び降りて一週間ほど腰を抜かしたこと がある。」とした。
}

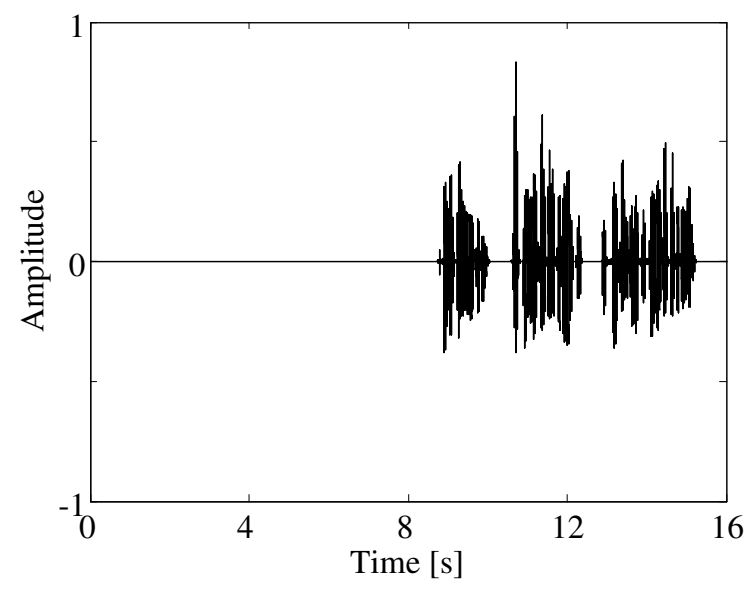

図 7 音声（女性）

Fig. 7 Speech signal (female)

\section{2 雑音パワーの推定精度の評価}

推定精度の評価指標として, 雑音パワー推定䛊差 $e(i)$ を

$e(i)=10 \log _{10}\left(\frac{1}{M} \sum_{\omega=0}^{M-1} \frac{\left|E\left[\left|N_{i}(\omega)\right|^{2}\right]-E\left[\left|\hat{N}_{i}(\omega)\right|^{2}\right]\right|}{E\left[\left|N_{i}(\omega)\right|^{2}\right]}\right)$

として定義した ${ }^{4}$ 。ここで， $M$ は平均する範囲を決定 するサンプル数を表し， $M=128$ とする。上式は，処 理フレーム $i$ における雑音パワー推定值と目標值の誤 差の大きさを評価できる。

図 8〜図 11 に各雑音を用いた場合の $e(i)$ の時間推 移をそれぞれ示す。縦軸が推定誤差, 横軸が時間であ る。従来手法の誤差が点線, 提案手法の誤差が太線で ある。

図 8〜図 10 に示すように, 定常性の高い 3 種類の 雑音に対し, 提案手法の推定精度は従来手法より優れ ている。雑音区間（0～ $8 \mathrm{~s})$ においては，提案手法の 推定精度が従来手法より平均で約 $5 \mathrm{~dB}$ 向上している。 音声成分のない雑音区間でさえ推定精度が改善した理 由として, 従来手法が入力信号のパワースペクトル平 均值の最小值を選択する手法であるため, 従来手法に おいて目標值である雑音パワーとの間に大きな誤差が 生じたためと考元られる。また，音声区間（8～16 s においては, 提案手法の推定精度が従来手法と比べ平 均で約 $7 \mathrm{~dB}$ 向上している。このことは, 提案手法に

\footnotetext{
4 周囲雑音および音声は低域にパワーが集中するため, 残差パ ワーを目標値 $E\left[\left|N_{i}(\omega)\right|^{2}\right]$ で周波数ごとに正規化している。
} 


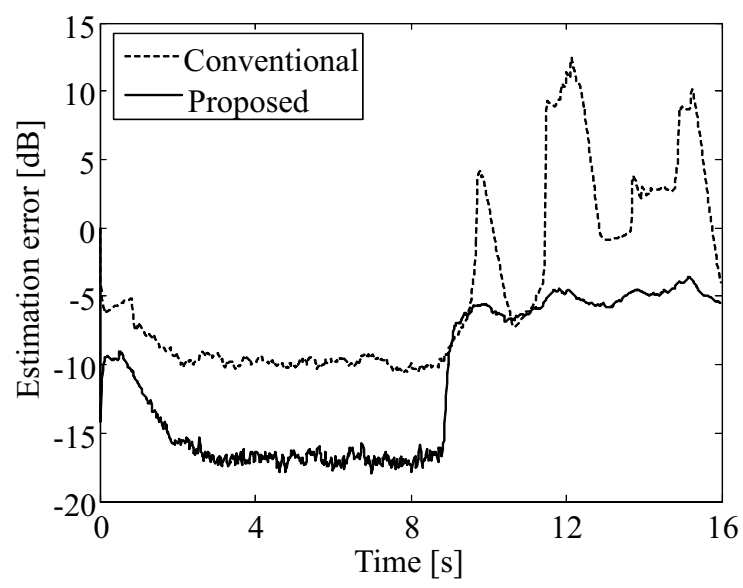

図 8 空調雑音の推定誤差

Fig. 8 Estimation error for air-conditioning noise

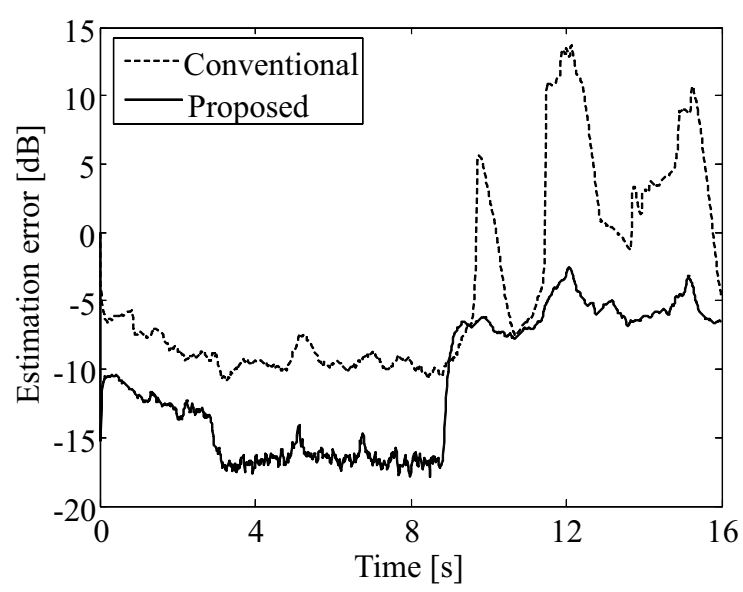

図 9 車内雑音の推定誤差

Fig. 9 Estimation error for vehicle noise

より，空調雑音のような定常的な雑音だけでなく比較 的推定が困難である時間変動を伴う雑音環境下でも, 従来手法に比べ音声区間中の雑音パワーの推定精度を 向上できたことを示す。

しかしながら，図 11 に示すように，オフィス雑音 に対しては, 雑音区間における提案手法の推定精度が 従来手法々同程度であった。提案手法では, 仮定 (1) において閉区間内での雑音の定常性を仮定している。 これに対し，オフィス雑音には非定常性の高い成分が 含まれるため, 仮定 (1) が成り立たず推定精度が低 下したと考えられる。音声区間においては，提案手法 は音声成分の影響を抑え, 推定精度を従来手法と比べ 平均で約 $4 \mathrm{~dB}$ 改善できた。

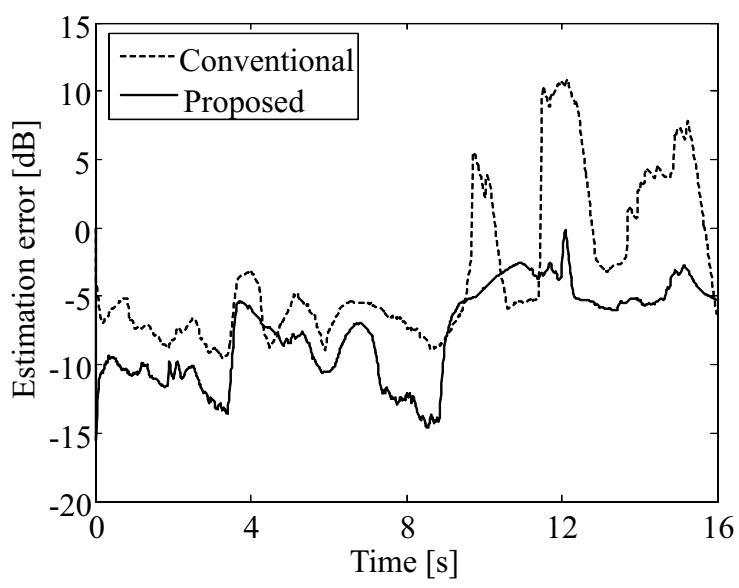

図 10 街頭雑音の推定誤差

Fig. 10 Estimation error for street noise

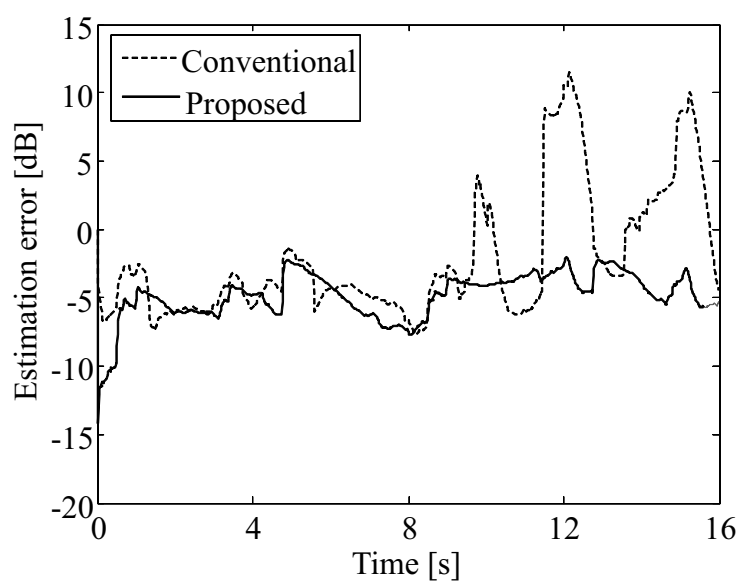

図 11 オフィス雑音の推定誤差

Fig. 11 Estimation error for office noise

\section{3 雑音抑圧性能の評価}

雑音抑圧性能を評価するため, 従来手法, および提 案手法，それぞれに対し，式(3)のゲイン計算式に基づ くSTSA 雑音抑圧処理を組み合わせて実験を行った。 図 12 に入力信号, 図 13 に従来手法の雑音抑圧処理 後の信号, 図 14 に提案手法の処理信号を示す。入力信 号は, 図 7 の音声に街頭雑音を加算した信号とした。 これらの時間波形およびスペクトログラムからわかる ように、雑音区間（0～ $8 \mathrm{~s})$ において，提案手法と従 来手法は雑音を同程度抑えている。音声区間（8～16 s）においては，従来手法に比べ音声 $s(k)$ の波形がよ り復元されていることがわかる。 

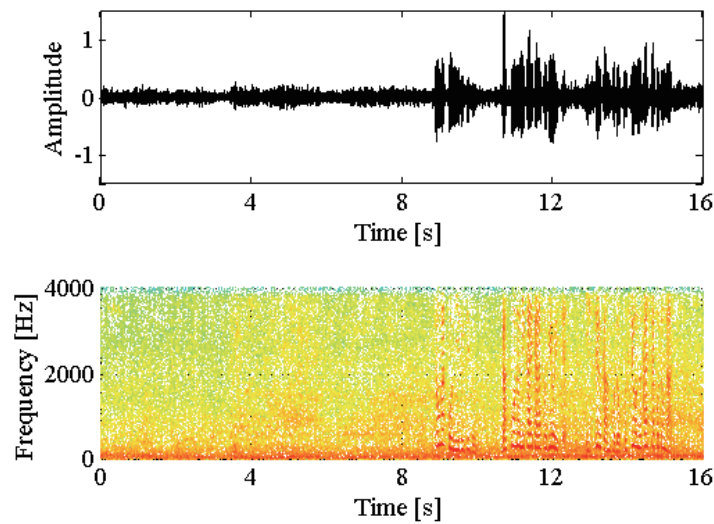

図 12 入力信号（処理前信号）

Fig. 12 Input signal (original signal)
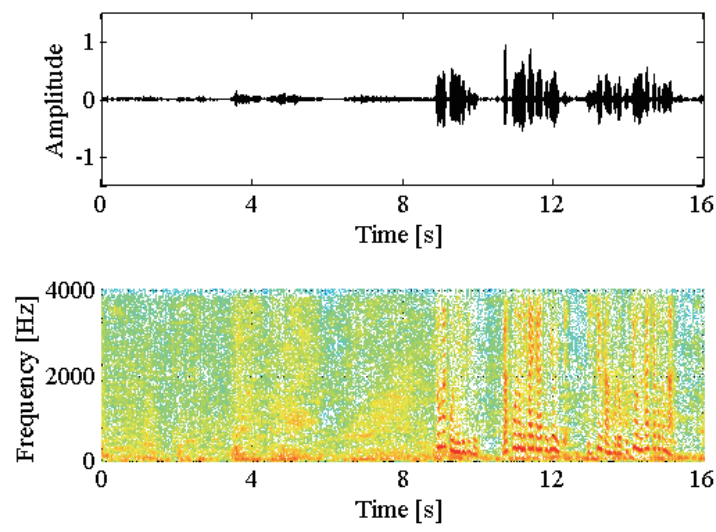

図 13 従来手法の処理信号

Fig. 13 Output signal from conventional method

図??は，上述した雑音区間の各信号のパワーエンベ ロープ, 図 16 は，音声区間の各信号のパワーエンベ ロープを表す。縦軸がパワー, 横軸が時間である。図 ??および図 16 より，提案手法の雑音区間中の雑音抑 圧量が従来手法と同程度であり，音声区間中において 提案手法が従来手法に比べ音声の欠損が少ないことが 確認できる。入力信号（処理前の信号）と処理後の信 号のレベル差より求めた雑音区間中の雑音抑圧量は, 従来手法と提案手法でそれぞれ $11.13 \mathrm{~dB}$ と $11.33 \mathrm{~dB}$ であった。

音声区間中の品質については，複数の評価デー夕を 用いて定量評価を行った。雑音抑圧性能の評価尺度とし て, 雑音抑圧量 (Noise reduction rate:NRR) [18], 歪
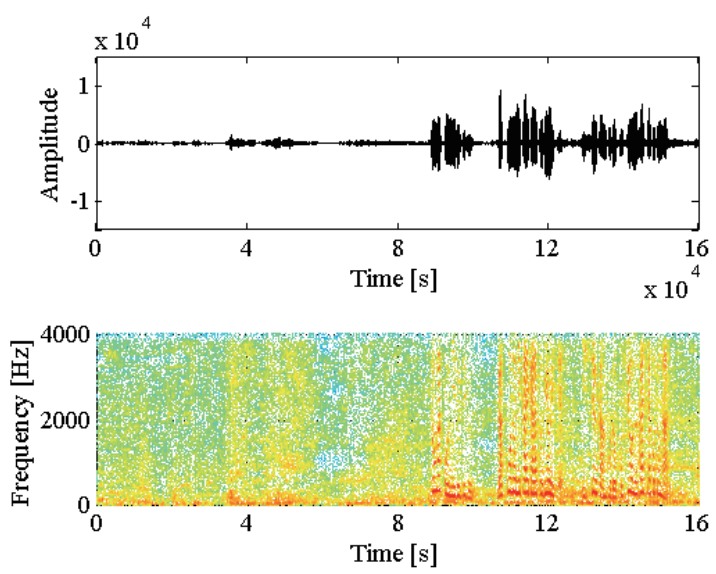

図 14 提案手法の処理信号

Fig. 14 Output signal from proposed method

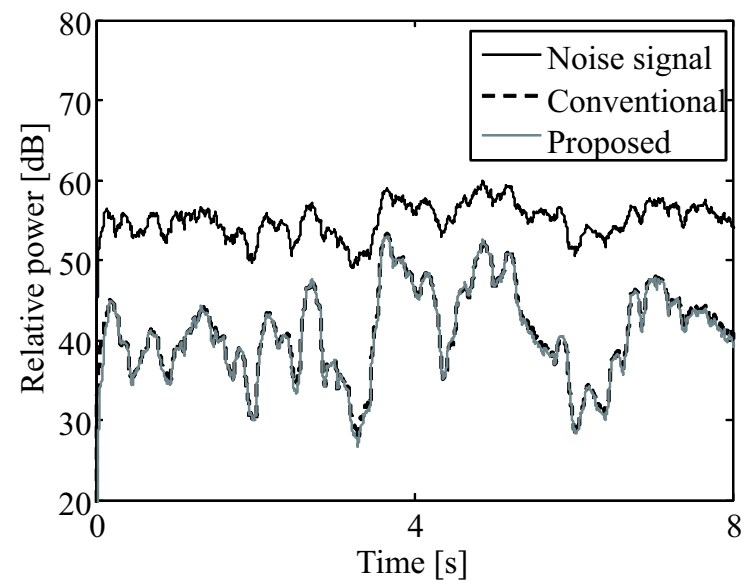

図 15 各信号のパワーエンベロープ（雑音区間）

Fig. 15 Power envelope of each signal (noise section)

み評価尺度として信号対歪み比（Signal-to-distortion ratio:SDR) [19] と対数スペクトル歪み (Log spectral distortion：LSD）[20]をそれぞれ用いた。評価に用い る音声 $s(k)$ を, 図 17 に示す男性 3 名, 女性 3 名の音 声から構成される長さ $180 \mathrm{~s}$ の音声とした。 $180 \mathrm{~s}$ 間 全て音声区間である。音声サンプルは, ITU-T 勧告 P.800 に準拠して録音された。また，周囲雑音 $n(k)$ と して, 電子協騒音データベースの雑音空調雑音, NTT アドバンステクノロジ株式会社の環境騒音データベー スの車内雑音, 街頭雑音, およびオフィス雑音を用い た。入力信号の SNR は，それぞれ，0 dB，-6 dB，6 $\mathrm{dB} ， 9 \mathrm{~dB}$ である。NRR は值が大きいほど高い雑音 


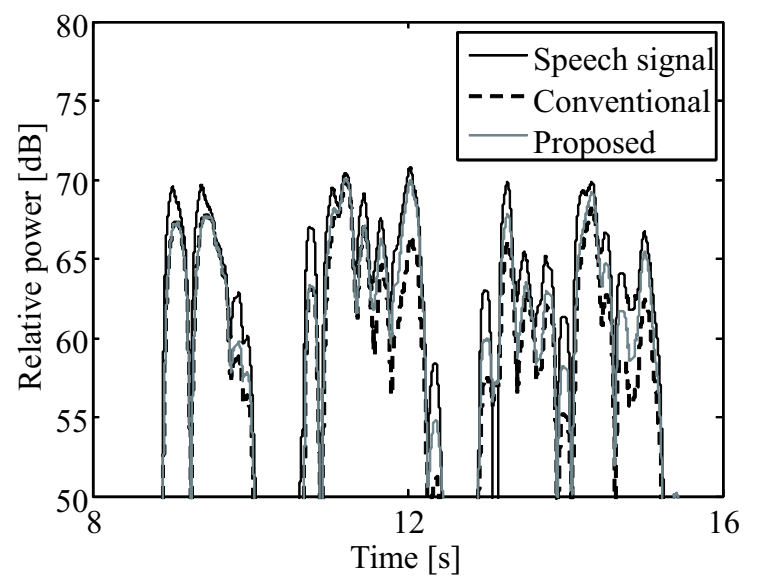

図 16 各信号のパワーエンベロープ（音声区間）

Fig. 16 Power envelope of each signal (speech section)

抑圧性能を示すものであり，次式で定義される。

$$
\mathrm{NRR}=\mathrm{SNR}_{\text {out }}[\mathrm{dB}]-\mathrm{SNR}_{\mathrm{in}}[\mathrm{dB}]
$$

ここで, $\mathrm{SNR}_{\text {Out }}$ は出力信号 (雑音抑圧処理後の信号) の SNR, SNR $\mathrm{Sn}_{\text {in }}$ は入力信号 (処理前の信号) の SNR を示す。SDR は值が大きいほど時間波形の歪みが小 さいことを示すものであり，次式より計算する。

$$
\begin{gathered}
\mathrm{SDR}=10 \log _{10}\left(\frac{\sum_{k=0}^{K-1} s^{2}(k)}{\sum_{k=0}^{K-1}\{s(k)-\lambda \hat{s}(k)\}^{2}}\right) \\
\lambda=\sqrt{\frac{\sum_{k=0}^{K-1} s^{2}(k)}{\sum_{k=0}^{K-1} \hat{s}^{2}(k)}}
\end{gathered}
$$

ここで, $\hat{s}(k)$ は処理後の信号, $K$ は入力信号のサン プル数を表し， $K=1440000 （ 180 \mathrm{~s}$ に相当）である。 LSD は信号のスペクトル包絡の歪みの大きさを示す 尺度であり，次のように定義される。

$\mathrm{LSD}=\frac{\sqrt{2} 10}{\log _{e} 10} \sqrt{\mathrm{E}\left[\frac{1}{2}\left(c_{0}-\hat{c}_{0}\right)^{2}+\sum_{m=1}^{\infty}\left(c_{m}-\hat{c}_{m}\right)^{2}\right]}$

ここで， $c_{m}$ および $\hat{c}_{m}$ は，それぞれ入力信号と処理後 の信号の $m$ 次のケプストラム係数を示す。 $\mathrm{E}[\cdot]$ は期待 值演算子を表す。
表 1 NRR による性能比較

Table 1 Comparison by NRR

\begin{tabular}{ccc}
\hline & Conventional & Proposed \\
\hline Air-conditioning noise & $7.55 \mathrm{~dB}$ & $8.51 \mathrm{~dB}$ \\
Vehicle noise & $7.68 \mathrm{~dB}$ & $8.8 \mathrm{~dB}$ \\
Street noise & $7.23 \mathrm{~dB}$ & $8.06 \mathrm{~dB}$ \\
Office noise & $3.40 \mathrm{~dB}$ & $2.93 \mathrm{~dB}$ \\
\hline
\end{tabular}

表 2 SDR による性能比較

Table 2 Comparison by SDR

\begin{tabular}{ccc}
\hline & Conventional & Proposed \\
\hline Air-conditioning noise & $6.07 \mathrm{~dB}$ & $6.42 \mathrm{~dB}$ \\
Vehicle noise & $3.98 \mathrm{~dB}$ & $4.05 \mathrm{~dB}$ \\
Street noise & $10 \mathrm{~dB}$ & $13.09 \mathrm{~dB}$ \\
Office noise & $9.26 \mathrm{~dB}$ & $10.73 \mathrm{~dB}$ \\
\hline
\end{tabular}

表 3 LSD による性能比較

Table 3 Comparison by LSD

\begin{tabular}{ccc}
\hline & Conventional & Proposed \\
\hline Air-conditioning noise & $7.34 \mathrm{~dB}$ & $5.93 \mathrm{~dB}$ \\
Vehicle noise & $9.72 \mathrm{~dB}$ & $9.1 \mathrm{~dB}$ \\
Street noise & $5.76 \mathrm{~dB}$ & $3.74 \mathrm{~dB}$ \\
Office noise & $6.45 \mathrm{~dB}$ & $5.83 \mathrm{~dB}$ \\
\hline
\end{tabular}

表 1 , 表 2 , 表 3 に, NRR, SDR, LSD の従来手法 と提案手法の性能比較結果をそれぞれ示す。これらの 值は，180 $\mathrm{s}$ 間の平均より計算された。これらの結果 より, 空調雑音, 車内雑音, および街頭雑音の 3 つの 周囲雑音において, 提案手法が従来手法より優れてい ることがわかる。しかしながら，オフィス雑音に対し ては，提案手法により SDR と LSD は改善したもの の，NRR は従来手法より低い值となった。これらの 結果より, 提案手法は, 空調雑音, 車内雑音, および 街頭雑音のような, 定常性の高い雑音に対し有効性が 高いといえる。オフィス雑音のような非定常性の高い 雑音に対しては, 提案手法による音声歪み低減は確認 できたものの, 雑音抑圧量の改善は本実験で見られな かった。

Journal of Signal Processing, Vol. 18, No. 1, January 2014 


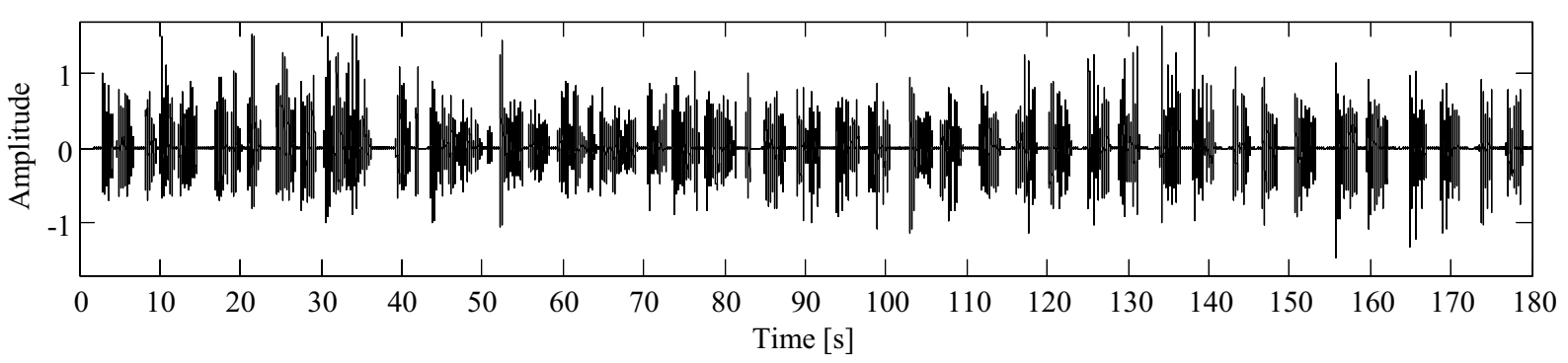

図 17180 秒の音声

Fig. 17 Speech signal of 180 seconds

\section{6. まとめ}

本論文では，STSA 雑音抑圧処理に不可欠な雑音パ ワー推定の精度改善を目的とした。提案手法は, 周囲 雑音の周波数ごとの振幅が短区間で一定であり, 且つ 音声信号が非定常であることを仮定し，入力信号に含 まれる周囲雑音の割合を周波数ごとに逐次推定するこ とで, 音声区間でも雑音パワー推定を可能とする。計 算機シミュレーションにおいて, 空調雑音, 車内雑音, および街頭雑音のような, 定常性の高い雑音に対し, 入力信号のパワースペクトル平均值の最小值を選択し て雑音パワーとする従来手法よりも，雑音パワーの推 定精度が向上することを示した。また，STSA 雑音抑 圧処理に適用することにより, 定常性の高い雑音に対 し, 従来手法と比較して高い雑音抑圧性能と音声品質 を達成した。しかしながら, 本手法においては, 雑音 の定常性を仮定するため非定常性の高い雑音に対応で きないという事実があり，実験ではオフィス雑音に対 して優位な差は見られなかった。このような非定常性 の高い雑音に対し, いかに対応するかが今後の課題で ある。

\section{参考文献}

[1] C. Beaugeant, V. Turbin, P. Scalart and A. Gilloire: New optimal filtering approaches for hands-free telecommunication terminals, Signal Process., Vol. 64, No. 1, pp. 33-47, Jan. 1998.

[2] 阪内澄宇, 羽田陽一, 田中雅史, 佐々木潤子, 片岡章俊: 雑音 抑圧及びエコー抑圧機能を備えた音響エコーキャンセラ，信 学論 (A), Vol. J87-A, No. 4, pp. 448-457, Apr. 2004.

[3] S. F. Boll: Suppression of acoustic noise in speech using spectral subtraction, IEEE Trans. Acoustics, Speech and Signal Proc., Vol. 27, No. 2, pp. 113-120, Apr. 1979.
[4] J.S. Lim and A.V. Oppenheim: Enhancement and bandwidth compression of noisy speech, Proc. IEEE, Vol. 67, No. 12, pp. 1586-1604, Dec. 1979.

[5] Y. Ephraim and D. Malah: Speech enhancement using a minimum-mean square error short-time spectral amplitude estimator, IEEE Trans. Acoustics, Speech and Signal Proc., Vol. 32, No. 6, pp. 1109-1121, Dec. 1984.

[6] 加藤正徳, 杉山昭彦, 芹沢昌宏: 重み付き雑音推定と MMSE STSA 法に基づく高音質雑音抑圧, 信学論 (A), Vol. J87-A, No. 7, pp. 851-860, Jul. 2004.

[7] A. Benyassine et al.: ITU-T Recommendation G.729 Annex B: a silence compression scheme for use with G.729 optimized for V.70 digital simultaneous voice and data applications, IEEE Commun. Mag., Vol. 39, No. 9, pp. 64-73, Sep. 1997.

[8] R. Martin: Spectral subtraction based on minimum statistics, Proc. EUSIPCO'94, pp. 1182-1185, Sept. 1994.

[9] R. Martin: An MMSE soft-decision estimator for combined noise and residual echo reduction, Proc. IWAENC'99, pp. 84-87, Sept. 1999.

[10] T. Gulzow: Spectral-subtraction-based speech enhancement using a new estimation technique for nonstationary, Proc. IWAENC'99, pp. 76-79, Sept. 1999.

[11] S. Gustafsson, R. Martin, P. Jax and P. Vary: A psychoacoustic approach combined acoustic echo cancellation and noise reduction, IEEE Trans. Speech and Audio, Vol. 10, No. 5, pp. 245-255, Jul. 2002.

[12] K. V. Sorensen and S. V. Andersen: Speech enhancement with natural sounding residual noise based on connected time-frequency speech presence regions, EURASIP Journal on Applied Signal Process., Vol. 2005, No. 1, pp. 2954-2964, Jan. 2005.

[13] R. Martin: Bias compensation methods for minimum statistics noise power spectral density estimation, Signal Process., Vol. 86, No. 6, pp. 1215-1229, Jun. 2006.

[14] 佐々木潤子, 田中雅史: マスキング効果を用いた低歪み雑音 低減方式の検討，信学技報， EA98-106, Dec. 1998.

[15] ITU-T Recommendation P.800 - Methods for subjective determination of transmission quality, Aug. 1996.

[16] 電子協騒音データベース: http://research.nii.ac.jp/ src/JEIDA-NOISE.html.

[17] 環境騒音データベース: http://www.ntt-at.co.jp/ page.jsp?id=1793\&content_id=362. 
[18] 猿渡洋: アレー信号処理を用いたブラインド音源分離の基礎, 信学技報，EA2001-7，pp. 49-56, Apr. 2001.

[19] 堀井圭祐, 福森隆寛, 森勢将雅, 中山雅人, 西浦敬信, 山下洋 一, 南條浩輝: 雑音下音声受音における Weighted 反復スペク トル減算法を用いたミュージカルノイズの低減, 信学論 (D), Vol. J96-D, No. 3, pp. 664-674, Mar. 2013.

[20] P. Jax and P. Vary: An upper bound on the quality of artificial bandwidth extension of narrowband speech signals, Proc. ICASSP2002, Vol. 1, pp. 237-240, May 2002

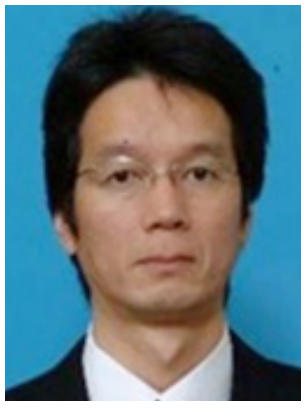

中川 朗 1992 年 九工大・情報卒, 1994 年 同大大学院修士課程了。同年, 日本電信電話株式会社 $(\mathrm{NTT})$ 入社。 現在, NTT メディアインテリジェン 又研究所主任研究員。2001 年 電子情 報通信学会学術奨励賞, 2001 年 日本 音響学会佐藤論文賞受賞。日本音響学 会会員。

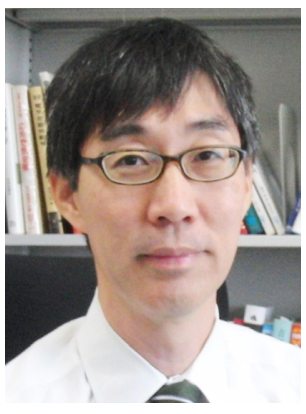

羽田 陽一 1987 年 東北大・理・物 理卒, 1989 年 同大大学院理学研究科 修士課程了。同年, 日本電信電話株式 会社 (NTT) 入社。以来, 音響信号処 理に関する研究開発に従事。博士（情 報科学)。2012 年 10 月より電気通信 大学情報理工学研究科総合情報学専攻 教授。1996 年 電子情報通信学会学術 奨励賞，1997 年 電子情報通信学会第 34 回業績賞, 1998 年 日本音響学会 粟屋潔学術奨励賞, 2001 年 電子情報 通信学会論文賞, 同年日本音響学会佐 藤論文賞受賞。電子情報通信学会, 日

本音響学会，IEEE 各会員。

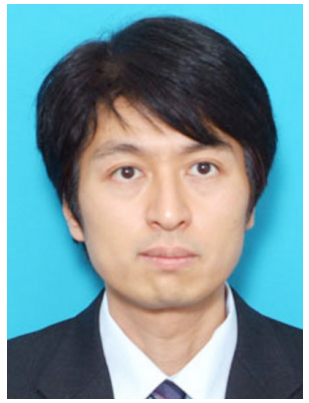

島内 末廣 1991 年 東工大・丁． 電子物理工卒, 1993 年 同大大学院修 士課程了。2007 年 同大大学院博士課 程了。博士 (工学)。1993 年 日本電 信電話株式会社（NTT）入社。現在、 NTTメディアインテリジェンス研究 所主任研究員。電子情報通信学会, 日 本音響学会，IEEE 各会員。

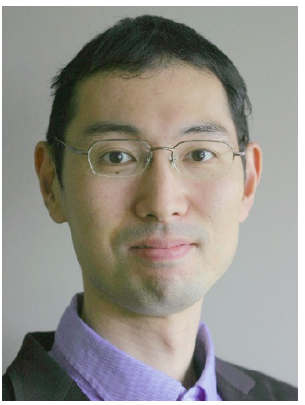

日岡 裕輔 2000 年 慶大・理工・シ ステムデザイン工卒, 2005 年 同大大 学院後期博士課程了。博士 (工学)。同 年日本電信電話 $(\mathrm{NTT})$ 入社。NTT サイバースペース研究所にて, マイク ロホンアレー信号処理の研究に従事。 2010 年より 1 年間, ニュージーラン ド, Victoria University of Wellington 客員研究員, 2013 年 ニュージー ランド, University of Canterbury, Lecturer，現在に至る。IEEE シニア 会員, 日本音響学会会員。

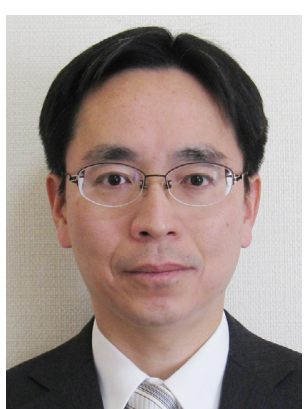

大室 仲 1990 年 3 月名古屋大学 大学院工学研究科電気・電子工学専攻 修士課程了。同年 4 月 日本電信電話 (NTT) 入社。以来，主に高能率音声 符号化とVoIP アプリケーションの研 究・開発, ITU-T 標準化に従事。NTT メディアインテリジェンス研究所 主 幹研究員。電子情報通信学会, 日本音 響学会, IEEE 各会員。

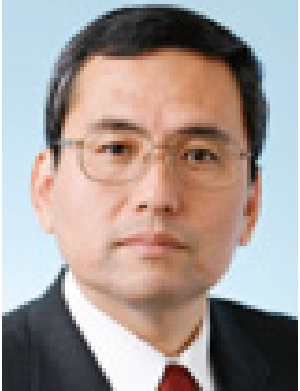

各会員。
片岡 章俊 1984 年 同志社大 ・工 電気卒, 1986 年 同大大学院修士課程 了。同年 NTT 入社, 以来, 雑音·残響 抑圧, 音響マイクロホンアレー, 音声 強調, 音声の高能率符号化など音声・音 響信号処理の研究，ITU 音声符号化標 準化に従事。2008 年より龍谷大学・理 工学部・教授, 工博。1996 年, 2006 年 日本音響学会技術開発賞, 2003 年 全 国発明表彰特許庁長官賞。2006 年 電 子情報通信学会通信ソサイエテイ論文 賞 (Best PaperAward) 各受賞。電 子情報通信学会, 日本音響学会, IEEE

(2013 年 3 月 13 日受付; 2013 年 7 月 29 日再受付) 